
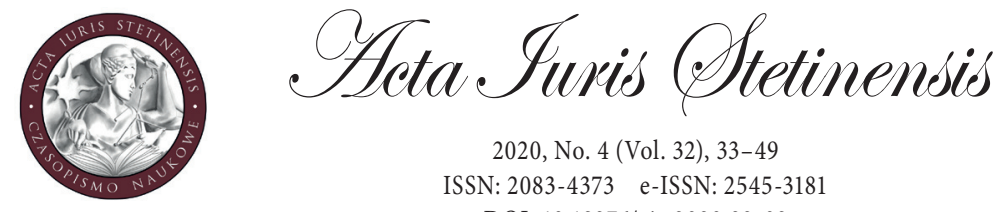

2020, No. 4 (Vol. 32), 33-49

ISSN: 2083-4373 e-ISSN: 2545-3181

DOI: $10.18276 /$ ais.2020.32-03

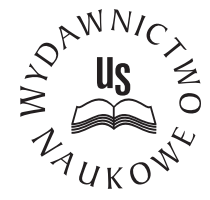

Karolina Mendecka

Ph.D.

University of Lodz, Poland

Faculty of Law and Administration

e-mail: mendecka.k@gmail.com

open Access

ORCID ID: 0000-0002-3575-4334

\title{
Born to Polish same-sex parents - a case study. A human rights perspective on birth certificate transcriptions
}

\begin{abstract}
This article is a case study regarding a recent resolution of the Supreme Administrative Court in Poland (the SAC). The Court found that a transcription of a foreign birth certificate, in which two people of the same sex are registered as parents, is not allowed under the Polish law and is contrary to ordre public. This paper focuses primarily on two aspects regarding the resolution. First, it addresses whether the best interest of the child principle was given due consideration. Second, it analyses whether the possible discriminatory treatment on the grounds of sexual orientation of the parents was adequately examined, with particular reference to the jurisprudence of the European Court of Human Rights (the ECtHR). This paper is divided into four parts. The background information pertaining to the issues at stake as well as the case itself are addressed in Part 1. Part 2 briefly summarises the SAC resolution and the judgement. Part 3 concentrates on deconstructing the best interest principle as an international and national standard. In Part 4 the ECtHR case-law is examined in order to provide a human rights perspective on the matter. This article concentrates on providing the perspective of a child and on the jurisprudence of the European Court of Human Rights, as it is a well-recognised international law-applying body that raises the threshold and quality of respecting human rights in the European continent. The final part summarises the paper and presents the conclusions.
\end{abstract}


It is going to be demonstrated that in light of the ECtHR jurisprudence, the SAC failed to adequately analyse that a difference in treatment of same-sex parents in comparison to other unmarried couples is reasonable, pursues a legitimate aim and that the treatment is proportional. Moreover, it will be argued that the SAC unsuccessfully demonstrated why primacy had been granted to the interest of the state and public order, instead of that of a child. The main goal of this paper is to highlight the importance of endorsing the child's perspective and the compelling need to carefully consider the child's best interest - in each and every case that involves their fate.

In order to achieve the purpose of this study, the research is based on the evaluation of the universal human rights documents relevant to the topic, as well as the analysis of the ECtHR jurisprudence related to the subject.

Keywords: best interest of the child, birth certificate transcript, European Court of Human Rights jurisprudence, same-sex parenthood

\section{Introduction}

In December 2019 the Supreme Administrative Court (the SAC) in Poland issued a resolution detrimental to the situation of children born to same-sex parents. Principally, the SAC ruled that the Polish law does not allow for a transcription of a foreign birth certificate, in which two people of the same sex are registered as parents. The scope of this resolution reaches far beyond this individual case - it conceivably influences the fate of many children, who, as a result, may face some difficulties in the future.

This paper concentrates on two main concerns regarding the SAC resolution. First, it is argued that the SAC did not adequately address the well-established best interest of the child principle. The Court instead repeatedly argued that the refusal to recognise two mothers as parents under the Polish law is justified by public policy. Ultimately, it can be said that the Supreme Administrative Court granted primacy to the interest of the state, not that of the child. Therefore, this article examines whether such reasoning is justifiable, especially according to international standards.

Secondly, it seems that the resolution did not adequately consider the possible discriminatory treatment on the grounds of sexual orientation of the parents. Although the SAC addressed some of the jurisprudence of the European Court of Human Rights (the ECtHR), this paper aims to thoroughly review the prevailing 
case-law regarding $\mathrm{LGBTQ}^{1}$ issues pertaining to the Polish case (especially regarding same-sex parenthood).

It has to be highlighted however, that granting citizenship and a person's status is a prerogative of the state, and thus international law plays a limited role in that regard. For example, this has been brought up in the recent Court of Justice of the European Union judgment. The Grand Chamber reaffirmed that 'admittedly, a person's status, is a matter that falls within the competence of the Member States and EU law does not detract from that competence.' ${ }^{2}$ Nonetheless, Poland is still a member of a European community and therefore should respect European values as well as basic human rights and especially children's rights. Therefore, the main focus of this paper is aimed at investigating whether the SAC resolution is in line with contemporary European human rights standards, and especially whether the best interest of a child has been given due consideration.

\section{Background information pertaining to the case}

In this particular case, the applicant addressed the superintendent registrar to issue a transcript of a birth certificate of her child, where her partner was stated as the second parent. ${ }^{3}$ Both parents were females who have Polish citizenship and were explicitly mentioned in the British birth certificate. ${ }^{4}$ The request to issue a transcript was denied both by the register office and by the provincial governor to whom they eventually appealed. Subsequently, the Provincial Administrative Court rejected the complaint, arguing that recognising two mothers is contradictory to the ordre public.

The applicant filed a cessation appeal at the SAC. She argued that several provisions were misinterpreted, and emphasized that the transcription would not interfere with public order. She referred to Articles 8 and 14 of the European Convention on Human Rights, demonstrating that there had been an interference with

1 Abbreviation for: lesbian, gay, bisexual, transsexual, queer or questioning.

2 Case C-673/16 Coman and Others v Inspectoratul General, ECLI:EU:C:2018:385.

3 Resolution of the Supreme Administrative Court resolution of 2 December 2019, II OPS 1/19, ONSAiWSA 2020, No. 2, item 11.

4 It has to be highlighted that both parents were female and held Polish citizenship, therefore in this case other possible legal disputes did not emerge, as it might happen regarding cases involving e.g. surrogacy, see e.g.: Pilich, M., Mater semper certa est? Kilka uwag o skutkach zagranicznego macierzyństwa zastępczego z perspektywy stosowania klauzuli porządku publicznego, "Problemy Współczesnego Prawa Międzynarodowego, Europejskiego i Porównawczego" 2018, Vol. XVI, pp. 7-37. 
her and her partner's and their child's rights to private and family life. She raised that the Convention on the Rights of the Child had been violated, in particular: Article 2(1), Article 3(1), Article 7(2) and Article 8. In essence, it was pointed out that no measures protecting the child from discrimination due to its parents' sexual orientation were applied. Moreover, the applicant observed that the best interest of the child principle had not been adequately taken into consideration. The applicant highlighted that the refusal to issue the transcript of the birth certificate would have a result similar to statelessness and that it would deprive the child of recognising its family relations in relation to citizenship and consequently also its identity. ${ }^{5}$

The Polish Ombudsman concurred with the applicant's appeal. He pointed out that the PAC did not demonstrate why ordre public was at threat and highlighted that the application of the public order clause requires individual application and approach. Meanwhile, surprisingly, the Polish Ombudsman for Children stated that the transcription of the child's birth certificate in that case would be contrary to public policy. He did not raise any concerns regarding the child's best interest or issues with non-discrimination.

Up to this point, there were two differentiating approaches to the matter in question in Polish administrative jurisprudence. In some judgments it had been stipulated that recognising two parents of the same sex under Polish law would violate the basic principles of the Polish public policy. ${ }^{6}$ This arm of case-law pointed out, among other things, that 'parents' under Polish law denote only two people of different sex: a mother (female) and a father (male). This understanding stems from Article 18 of the Polish Constitution, which states: 'marriage, being a union of a man and a woman, as well as the family, motherhood and parenthood, shall be placed under the protection and care of the Republic of Poland.' ${ }^{7}$ Accordingly, the Schalk and Kopf $v$ Austria ${ }^{8}$ judgment was mentioned, where the ECtHR deemed

5 The applicant also argued a violation of the EU law: Article 20(2)(a) and 21(1) of the Treaty on the Functioning of the European Union (TFEU) signed on 13 December 2007, OJ C 326, 26.10.2012, pp. 47-390, that is the right to move and reside freely within the territory of the Member States. In addition, she argued violation of Article 7, 21(2), 24(2) and (3) of the Charter of Fundamental Rights of the European Union of 2 October 2000, OJ C 326, 26.10.2012, pp. 391-407.

6 See: judgement of the Supreme Administrative Court of 17 December 2014, II OSK 1298/13, LEX No. 1772336, as well as the judgements of the Provincial Administrative Courts (PAC): judgement of the Provincial Administrative Court in Gliwice of 6 March 2016, II SA/Gl 1157/15, LEX No. 2035383 and judgement of the Provincial Administrative Court in Kraków of 10 May 2016, III SA/Kr 1400/15, LEX No. 2056842.

7 Constitution of the Republic of Poland of 2 April 1997, Dz.U. (Journal of Laws) of 1997, No. 78, item 483 as amended.

8 ECtHR, Schalk and Kopf $v$ Austria, Application no. 30141/04, 2406.2010. 
that the European Convention on Human Rights (the ECHR) ${ }^{9}$ does not oblige member states to legally recognise same-sex marriages.

However, there was a significant shift in SAC jurisprudence in 2018. In a judgment issued on 10 October 2018 the SAC addressed the child's best interest and consequently argued that the refusal to issue a transcript infringes the rights of a child. ${ }^{10}$ In the 2018 judgment the Court argued that the transcript is, according to the law, obligatory and the ordre public cannot override that. On top of that, the SAC pointed out that children's rights have to take precedence in that situation, as was stipulated in the ECtHR jurisprudence (e.g. Mennesson $v$ France). ${ }^{11}$

These issues were also disputed in the Polish literature. Some authors welcomed the 2018 judgment with enthusiasm, arguing that the refusal to issue a transcript would result in chastising the child for the makeup of their family (i.e. for the fact that they have two mothers or two fathers, instead of parents of different sexes). ${ }^{12}$

However, the 2018 SAC judgment was criticised by Piotr Mostowik, who reckoned that the ruling addressed a problem that in fact falls outside of the scope of the case itself. The author also argued that the solution presented by the Court might 'destroy' the Polish system of registering the civil status from 'within. ${ }^{13}$

\section{The Supreme Administrative Court II OPS 1/19 resolution}

Due to these discrepancies in the jurisprudence, the adjudicating judges in the case concerned referred the legal question to the extended panel of 7 judges of the Supreme Administrative Court for them to adopt a resolution. ${ }^{14}$ The question was,

9 European Convention for the Protection of Human Rights and Fundamental Freedoms of 4 November 1950, ETS 5.

10 Judgement of the Supreme Administrative Court of 10 October 2018, II OSK 2552/16, LEX No. 2586953.

11 ECtHR, Mennesson v France, Application no. 65192/11, 26.06.2014.

12 Tadla, T., Glosa do wyroków Naczelnego Sądu Administracyjnego z dnia 10 i 30 października 2018 r. (sygn. akt: II OSK 1869/16, II OSK 2552/16), "Zeszyty Naukowe Sądownictwa Administracyjnego" 2019, No. 3, pp. 150-160, see: Krawiec, G., Transkrypcja zagranicznego aktu urodzenia dziecka osob tej samej płci pozostajacych w związku, "Studia Prawnicze. Rozprawy i Materiały" 2019, No. 2(25), p. 6.

13 Mostowik, P., Glosa do wyroku Naczelnego Sądu Administracyjnego z dnia 10 października 2018 r. (sygn. akt II OSK 2552/16), "Zeszyty Naukowe Sądownictwa Administracyjnego" 2019, No. 4, p. 142, see: Krawiec, G., op. cit, p. 6.

14 See: Skoczylas, A. and Swora, M., Administrative judiciary in Poland in search for fairness and efficiency - an overview, "Transylvanian Review of Administrative Sciences" 2007, No. 19E, p.122. 
in essence, whether the Polish administrative law allows for the transcription of a foreign birth certificate, where two people of the same sex are named as parents.

The SAC indicated that the transcription of a birth certificate has to be literal and adequate, both linguistically and formally (but it is not a translation). In other words, some modifications are allowed; however, under no circumstances they can be substantial. The Polish bill regarding birth status requires to explicitly mention a male as a father. ${ }^{15}$ Consequently, although the transcript is obligatory, the administrative body nonetheless can refuse to issue such document. The SAC agreed that the transcription would result in violating basic principles of Polish public order. The ordre public clause, according to the SAC, constitutes a legal safeguard against effects of foreign acts that are contradictory to basic (including constitutional) values. In this case, the Polish legislator requires that parents be of opposite sexes. Not only does Polish law not acknowledge same-sex parents, it does not recognise same-sex unions. Accordingly, the coherence of the Polish legal system and public policy would be endangered if documents containing information such as a birth certificate recognising two mothers as parents were acknowledged. Therefore, the SAC pointed to the link between the birth certificate in question and the ordre public. The SAC stated that recognising a 'father' who is not male is not possible and would constitute a breach of the aforementioned public order.

To support its reasoning, the SAC referred to the ECtHR jurisprudence and highlighted that states enjoy a wide margin of appreciation regarding same-sex couples (e.g. Paradiso and Campanelli $v$ Italy ${ }^{16}$, Orlandi and Others $v$ Italy ${ }^{17}$ and Oliari and Others $v$ Italy $\left.^{18}\right)$. Moreover, the SAC argued that the protection of the European Convention of Human Rights does not directly impose an obligation to issue a transcript of a birth certificate where people of the same sex are recognised as parents. The SAC referred to the Advisory Opinion issued by the Great Chamber of the European Court of Human Rights on 10 of April 2019. ${ }^{19}$ In that opinion, the ECtHR stated that the refusal to enter certain documents into the registry does not amount to the violation of the right of a child to a private life according to Article 8

15 See: Act of 28 November 2014 on civil status records, Dz.U. (Journal of Laws) of 2014, item 1741 as amended.

16 ECtHR, Paradiso and Campanelli v Italy, Application no. 25358/12, 27.04.2012.

17 ECtHR, Orlandi v Italy, Application no. 26431/12, 26742/12, 44057/12 and 60088/12, 14.12.2017.

18 ECtHR, Oliari v Italy, Application no. 18766/11 and 36030/11, 21.07.2015.

19 The Grand Chamber, Advisory Opinion concerning the recognition in domestic law of a legal parent-child relationship between a child born through a gestational surrogacy arrangement abroad and the intended mother, issued on 10 April 2019, P16-2018-001. 
of the ECHR, if there are available some other measures that are in accordance with the best interest of the child.

However, the SAC recognised that such interpretation of law cannot limit the right of a child to receive a personal number or ID, merely because the foreign birth certificate cannot be transcribed. Therefore, in the view of the Supreme Administrative Court, there are no obstacles for the child to receive an ID and a passport because to issue those documents, the British certificate could be used. Only when the administrative body refused to grant those documents, could the Court analyse the international and European Union law.

Therefore, on the face of it, the Supreme Administrative Court's reasoning seems comprehensive and logical. However, at least two main issues with the SAC resolution have to be addressed. First, the best interest of the child principle has not been given due consideration. It is well-recognised under both international and domestic laws that in all actions concerning children, his or her best interest should be of primary consideration. Second, the SAC resolution concerning the transcript of the birth certificate does demonstrate a route for children born to same-sex parents. However, the burden of this task is shifted onto the citizen, not onto the state.

What is more, although the obligation to seek the necessary documents relies solely on the citizen, it is neither clear nor certain whether he or she will not face further difficulties. In other words, the plight of the child is not foregone, as there can be more obstacles on the way. It therefore raises concern whether a fair balance was struck between the rights of a child and the frequently mentioned public order clause, which is discussed below.

It has to be noted that in the Polish literature the SAC resolution has been received with acclaim by some authors. ${ }^{20}$ For example, Michał Wojewoda agrees with the judgment with caution. He points out the redundant manner in which the SAC invoked the public order clause. ${ }^{21}$

Meanwhile, Piotr Mostowik highlights that the refusal to issue a transcript does not completely eradiate the possibility to settle some issues affecting the child (in

20 Notably, it has also been reviewed in Wiącek, M., Omówienie do uchwały NSA $z$ dnia 2 grudnia 2019 r., II OPS 1/19, “Zeszyty Naukowe Sądownictwa Administracyjnego" 2020, No. 1, pp. 163171.

21 While Wojewoda agreed with the overall argumentation provided by the SAC, he argued that it was unnecessary to invoke ordre public from Article 7 of the Private International Law (in addition to the ordre public provision from the bill on birth status), as it does not pertain to birth certificate transcription, see: Wojewoda, M., Zagraniczne rodzicielstwo osób jednej płci a rejestracja stanu cywilnego w Polsce - glosa do uchwały Naczelnego Sądu Administracyjnego z 2.12.2019 r., II OPS 1/19, "Europejski Przegląd Sądowy" 2020, No. 8, p. 34; Act of 4 February 2011 - Private International Law, consolidated text: Dz.U. (Journal of Laws) of 2015, item 1792. 
particular: to issue a temporary passport for the child). In addition, the transcript of this document in his view could even infringe the fundaments of the Polish legal system as well as threaten the foundation of family law. Consequently, he argues that the general rules of registering a civil status that apply to all citizens would be destroyed if the transcript had been issued in this 'casuistic' instance. ${ }^{22} \mathrm{He}$ also appeals to the naturam non imitator argument in support of the resolution, and proposes that any possible objections should not be aimed towards the SAC resolution or towards Polish law, but the criticism should instead be directed towards other countries that introduce those 'unusual resolutions to the descent of the child'. In other words, according to Mostowik, the foreign document in fact 'strips' the child of his biological and genetic identity, while the Polish legal system protects children. ${ }^{23}$

Conversely, Grzegorz Krawiec points out that the best interest of the child should have 'absolute priority', especially in cases where there are reasonable doubts (as in this case, taking into consideration the previous discrepancies in the SAC adjudication). He also notes that worldview conflicts should be completely irrelevant when the child's best interest is at stake. ${ }^{24}$

In stark contrast to Mostowik, Krawiec explains that the transcript does not infringe the public order and that a narrow interpretation of this clause is necessary, especially in this case. The fact that the Polish legal system does not (yet) recognise same-sex parenthood is not relevant, because the transcript merely certifies the existence of a foreign legal relationship, which in essence does not need to be recognised under Polish law..$^{25}$ It has been argued by Maciej Zachariasiewicz that it is disputable whether foreign law is being applied at all when issuing a transcript. Consequently, there is therefore a reasonable doubt whether the question of a transcript can be contrary to public order at all. ${ }^{26}$ What is more, Krawiec rightfully points out that the provisions regarding the transcript of a birth certificate are of a technical nature, therefore they should not override Constitutional and international norms and the best interest of a child principle. ${ }^{27}$

22 Mostowik, P., O żądaniach wpisu w polskim rejestrze stanu cywilnego zagranicznej fikcji prawnej pochodzenia dziecka od "rodziców jednoptciowych", "Forum Prawnicze" 2019, No. 6(56), p. 9.

23 Ibidem, pp. 25-26.

24 Krawiec, G., op. cit., p. 13.

25 Ibidem, p. 6.

26 Zachariasiewicz, M., Klauzula porzadku publicznego jako instrument ochrony materialnoprawnych interesów i wartości fori, Warszawa 2018, pp. 135-136, as pointed out by Krawiec, G., op. cit., p. 7.

27 Krawiec, G., op. cit., p. 8. 
Given all of the above, arguments supporting the stance that the transcript of a birth certificate where two females are regarded as parents infringes the ordre public are not convincing and should not be endorsed. It has to be noted that there are many more claims raised by some authors in support of the SAC resolution that provide various tortuous solutions arguing why and how to refuse the transcript of a birth certificate in accordance with Polish law. ${ }^{28}$ This article, however, concentrates on providing European and children's perspectives on the topic; therefore, the next section will concentrate on the best interest of a child - a provision that has gained international recognition.

\section{Best interest of a child}

The best interest principle has been present in the arena of international law since the 1959 Declaration of the Rights of the Child. ${ }^{29}$ Most importantly, it is now one of the four general principles in the Convention on the Rights of the Child (the CRC). ${ }^{30}$ Article 3 of the CRC stipulates that in all actions concerning children, whether undertaken by public or private social welfare institutions, courts of law, administrative authorities or legislative bodies, the best interest of the child shall be a primary consideration. ${ }^{31}$ Similar provisions can be found in other international documents, such as the Convention on the Elimination of all Forms of Discrimination against Women, ${ }^{32}$ the Convention on the Rights of Persons with Disabilities, ${ }^{33}$ as well as in various European Union documents, notably in the Charter of Fundamental Rights as well as other regulations and directives. ${ }^{34}$

The principle of the child's best interest is also widely recognised under the Polish legal system. In particular, it is considered to be one of the basic principles of

28 See: e.g.: Pilich, M., op. cit., p. 7 ff.

29 UN General Assembly, Declaration of the Rights of the Child (1959), A/RES/1386(XIV), https:// www.refworld.org/docid/3ae6b38e3.html (accessed 7.12.20).

30 Along with non-discrimination, right to life, survival and development and the right of the child to be heard.

31 The best interest principle is considered to be an 'umbrella' provision and it is also included in Articles 9, 18, 20, 21, 37 and 40.

32 Article 5, Convention on the Elimination of All Forms of Discrimination Against Women adopted by the General Assembly on 18 December 1979, United Nations, Treaty Series, Vol. 1249, p. 13.

33 Article 7, Convention on the Rights of Persons with Disabilities adopted by the General Assembly on 13 December 2006, A/RES/61/106, Annex I.

34 E.g. see: Directive 2011/36/EU of the European Parliament and of the Council of 5 April 2011 on preventing and combating trafficking in human beings and protecting its victims, and replacing Council Framework Decision 2002/629/JHA, OJ L 101, 15.4.2011, pp. 1-11. 
family law, ${ }^{35}$ as well as in civil and administrative law. ${ }^{36}$ The Polish Constitutional Tribunal, the Supreme Court and the Supreme Administrative Court all agree that the best interest of the child is paramount, especially in relation to other interests, e.g., the interest of parents or the state. ${ }^{37}$

Undoubtedly, the principle has gained worldwide recognition and acceptance, and it is not being contested, especially as the rule of procedure and to a certain degree as a substantive right. However, as the interpretative legal principle, the best interest principle remains ambiguous.

The phrasing of the principle has raised some concerns. According to the literal interpretation, 'a' is weaker than 'the' and arguably 'primary' is not as strong as, for example, 'paramount. ${ }^{38}$ It has to be noted that during the Convention's drafting, the wording of the principle was not broadly discussed. The CRC's travaux préparatoires show that the adoption of words -'a primary consideration' instead of 'the primary consideration', was made due to arguments that in some situations the interest of society or justice should prevail over the interest of the child. ${ }^{39}$ However, it has been argued that the choice of the indefinite article 'a' instead of the definite article 'the' during the drafting of the CRC was made solely to provide flexibility only in some extreme cases (a childbirth etc.). ${ }^{40}$ In General Comment 14 the Committee on the Rights of the Child evaluated that the best interest is not just primary, but a 'paramount' consideration in all actions concerning children by all public bodies. $^{41}$

The concept of the best interest principle as paramount has been developed also in the European Court of Human Rights. In Neulinger and Shuruk $v$ Switzerland the Court confirmed that there is 'currently broad consensus - including in

35 Smyczyński, T., Prawo rodzinne i opiekuńcze, Warszawa 2005, p. 19.

36 See: Radwański, Z., Dobro dziecka, in: Łopatka, A. (ed.), Konwencja o prawach dziecka a prawo polskie, Warszawa 1991, p. $51 \mathrm{ff}$.

37 See a broader analysis of the Polish jurisprudence regarding the best interest of the child in: Mendecka, K., Klauzula dobra dziecka w Konwencji o prawach dziecka $i$ w prawie polskim (wybrane problemy), "Acta Universitatis Lodziensis. Folia Iuridica” 2016, No. 77, pp. 25-36.

38 Parker, S., The best interest of the child - principles and problems, "International Journal of Law, Policy and the Family" 1994, Vol. 8, Issue 1, p. 28.

39 Deterick, S., A commentary on the United Nations Convention on the Rights of the Child, The Hague-Boston-London 1999, p. 88.

40 Alston, P., The best interest principle: towards a reconciliation of culture and human rights, "International Journal of Law, Policy and the Family" 1994, Vol. 8, Issue 1, pp. 1-25.

41 The Committee on the Rights of the Child in the General Comment 14 on 29 May 2013, CRC/C/ GC/14I, https://www.refworld.org/docid/51a84b5e4.html (accessed 7.12.2020). 
international law - in support of the idea that in all decisions concerning children, their best interest must be paramount. ${ }^{32}$

It is suggested that only rights-based interests can trump those of the child. In General Comment 6 the Committee pointed out that 'non rights-based arguments such as those relating to general migration control, cannot override best interest considerations. ${ }^{43}$ International human rights institutions' firm standpoint is that only an outstanding right-based interest can override the child's best interest; therefore, neither national security nor public safety can serve as grounds for decisions contrary to what is best for the child. ${ }^{44}$

In the next section, the ECtHR jurisprudence relating to the subject concerned will be addressed, not only in order to demonstrate how the best interest principle had been implemented throughout European case law, but to determine how the newest case law correlates to the facts of the case in question.

\section{ECtHR jurisprudence}

First, two concepts which play a substantial part in the ECtHR jurisprudence (especially in the cases that concern the suspect classification - sexual orientation), the European consensus and the margin of appreciation need to be briefly addressed. The European consensus refers to the level of uniformity present in the legal frameworks of the Member States of the Council of Europe on a particular topic. ${ }^{45}$ In other words, it is used to justify a margin of appreciation that is given to the member states - another concept created by the ECtHR jurisprudence. The European consensus paradigm as well as the margin of appreciation are useful tools that allow one to adequately interpret the European Convention on Human Rights, which is a 'living instrument'.

Addressing the case that involves the matter of same-sex parenthood, one still needs to discuss the question of a legal recognition of same-sex unions and marriages. The Supreme Administrative Court rightfully noted that whether to acknowledge same-sex unions or marriages still lies within a scope of a wide margin of appreciation. This was first confirmed in the infamous case Schalk and

42 ECtHR, Neulinger and Shuruck $v$ Switzerland, Application no. 41615/07, 6.07.2010.

43 The Committee on the Rights of the Child in the General Comment 6 on 17 May-3 June 2005, CRC/GC/2005/6, https://www2.ohchr.org/english/bodies/crc/docs/GC6.pdf (accessed 7.12.2020).

44 Ibidem, paragraph 86.

45 See: Benvenisti, E., Margin of appreciation, consensus and universal standards, "International Law and Politics" 1999, No. 31, pp. 843-854. 
Kopf $v$ Austria. However, what the SAC did not note is that since then (the Schalk judgment was issued in 2010) the jurisprudence of the European Court of Human Rights has significantly shifted towards a broader recognition of same-sex rights.

Naturally, there are several examples of judgments that bear resemblance to Schalk. For example, the case Gas and Dubois $v$ France $^{46}$ reaffirmed that for samesex couples there is no right to marry under Article 12 of the ECHR. Similarly, the ruling in Orlandi and others $v$ Italy stipulated that states do have wide discretion regarding that issue (however, the Court found a violation of Article 8 of the Convention, due to the fact that the state failed to strike a fair balance between the competing interests). Also, in Oliari and others $v$ Italy the ECtHR confirmed that the Convention does not require that same-sex marriages be allowed. Therefore, the Court found no violation of Article 12 (right to marry). However, if a different type of union is allowed, same-sex couples cannot be excluded, thus Article 8 was violated. ${ }^{47}$

There has been a shift in the Court's approach towards recognising a broader spectrum of the rights of same-sex couples as parents. One of the first significant cases was EB $v$ France $^{48}$, in which the Court deemed that if adoption is open to single persons, homosexuals cannot be discriminated against. The new approach is also apparent in $X$ and Others $v$ Austria.$^{49}$ At that time, under Austrian law unmarried same-sex couples were not legally permitted to access second-parent adoption. Meanwhile, this procedure was allowed for unmarried heterosexual couples. The Court found a violation of Article 14 in conjunction with Article 8, highlighting that there was no reasonable objective justification for limiting the second-parent adoption only to heterosexual couples. In other words, the Court did not agree that the margin of appreciation should be wide and observed that the couple had been discriminated against, and therefore their right to respect for a private and family life was violated, when read in conjunction with the non-discrimination provision.

The European Court of Human Rights in its jurisprudence stresses the importance of striking a fair balance between the interest of the applicant, especially the best interest of the child, and that of the state. The Mennesson $v$ France case concerned a surrogate mother. The French authorities refused to recognise the relationship between the parent and a child that had been established in the United

\footnotetext{
46 ECtHR, Gas and Dubois v France, Application no. 25951/07, 15.03.2012.

47 Which has also been a subject of concern in the ECtHR, Vallianatos and Others $v$ Greece, Application nos. 29381/09 and 32684/09, 7.11.2013.

48 ECtHR, EB v France, Application no. 43546/02, 22.01.2008.

49 ECtHR, $X$ and Others $v$ Austria, Application no. 19010/07, 19.02.2013.
} 
States. The main issue was that the woman who bore the child was entirely omitted in the birth certificate, whereas the document that was issued in California solely mentioned the French couple as parents. It was argued that a civil status cannot be disposed of and therefore it was contrary to French international public policy to recognise the Californian judgment. On the other hand, the French Court allowed for the children to live with the French parents, highlighting that it is in their best interest. The ECtHR deemed that there had been no violation of the right of the children or parents to respect of family life, but that there had been a violation of the private life. Regarding the family life, the ECtHR explained that in its view a fair balance was struck between child's best interest and the interest of the state. However, the Court explained that children would suffer legal uncertainty because of the non-recognition of family ties. In the Court's view there cannot be a contradiction between legal and social reality. ${ }^{50}$

Another ECtHR judgment concerning surrogacy is Foulon and Bouvet v France. ${ }^{51}$ The ECtHR highlighted that by refusing to transcribe the birth certificate of a child born through surrogacy its right to respect for private life was violated. In view of the Court, the rights of children (who were born as a result of internationally commercialised surrogacy) require that their parents be legally recognised. In other words, although states may prohibit surrogacy agreements, once the child is born through such a procedure, the law of a state cannot be used to prejudice the rights of the child, as it would be contrary to the child's best interest. The Court also highlighted that whenever a child is at stake, their best interest has to be paramount.

The Supreme Administrative Court in Poland, in the discussed resolution, mentioned some of the cases that are discussed in this paper. Although it seems that these cases had been primarily in the resolution's prerogative. Meanwhile, there is much more to those ECtHR cases than it had been demonstrated by the SAC.

For example, in Paradiso and Campanelliv Italy, the Grand Chamber found that there was no violation of Article 8 of the ECHR, as in accordance with the law the measures pursued a legitimate aim and were necessary in a democratic society. Therefore, the actions fell within the scope of the margin of appreciation. However, the ECtHR highlighted that the best interest of the child has to be given a primary consideration. In this case, the majority agreed that separation from the parents would not cause harm to the child. To the contrary, legalising the situation would create a situation as fait accompli. ${ }^{52}$ However, it is believed that this decision

50 ECtHR, Mennesson v France, Application no. 65192/11, 26.06.2014.

51 ECtHR, Foulon and Bouvet v France, Application nos. 9063/14 and 10410/14, 21.07.2016.

52 ECtHR, Paradiso and Campanelli v Italy, Application no. 25358/12, 27.04.2012. 
is case-specific, especially in light of the later jurisprudence. Nonetheless, Paradiso and Campanelli v Italy demonstrates that there are some factors that the Supreme Administrative Court in Poland did not take into consideration, namely not only the brief analysis of the family life, but also the thorough investigation of the child's private life and its best interest.

\section{Conclusions}

There is no doubt that the Supreme Administrative Court's resolution is substantiated and well-argued. Substantially, the SAC made comprehensive points and indicated the procedures that the applicants and their child may follow. However, it has to be highlighted that it is uncertain whether this route will indeed provide a feasible solution in action. Even the authors who acclaimed the resolution address concerns about the future. Though one might agree that it is inadmissible to transcribe birth certificates in such situations, there soon will be other complicated instances to which Polish law should adequately respond in some way. As Michał Wojewoda indicates, the Polish legal register should be prepared to take into account constructions - such as a marriage or death certificate of a person who has parents of the same sex - that are unavailable under Polish law. ${ }^{53}$ It remains to be seen how practice and jurisprudence will respond to circumstances in light of the SAC resolution. Nonetheless, these example adversities demonstrate that shifting the responsibility onto the applicant is - in many ways - problematic and may in itself infringe the child's (and person's) interest - especially its right to citizenship, movement and identity.

Notwithstanding, this article aimed to address some other concerns that could have been examined by the SAC in line with the recent ECtHR jurisprudence as well as with the best interest of the child principle. In particular, it has been established in Part 3 that the child's interest is paramount, therefore primacy cannot be automatically granted to the interest of the state - or as in this case, to the ordre public clause. Although the SAC provided some reasoning behind its findings, it failed to provide a thorough explanation on how the balance between the two competing interests was fairly struck. Without a doubt, in this respect, the SAC's resolution is unsatisfactory. In other words, de facto and de jure situation of children born to same-sex couples still continue to be in many ways uncertain and therefore they remain on the periphery of Polish society.

53 Wojewoda, M., op. cit., p. 38. 
Secondly, the analysis of the situation of same-sex parents is insufficient. It has to be noted that the reiteration of Article 18 of the Polish Constitution has nothing to do with the case at all, and it most certainly does not support the findings. Highlighting that marriage, under Polish law, is a union between a man and a woman is not relevant while discussing the issue of parenthood. For decades now children have been born 'out of wedlock ${ }^{54}$, therefore it is not at all relevant how the Polish lawmaker regulates the issue. To the contrary, it is crucial to recognise the social reality, and secondly to compare the situation of same-sex parents to that of heterosexual couples that wish to have the birth certificate of their child transcribed. The ECtHR came up with a comprehensive test that allows to determine, whether there was discriminatory treatment. Accordingly, treatment is discriminatory if (1) it has no objective and reasonable justification, (2) if it does not pursue a legitimate aim and (3) when there is no reasonable relationship of proportionality between the means employed and the aim sought to be realised..$^{55}$ Therefore, as in the aforementioned case $X$ and Others $v$ Austria, if the transcription would be allowed for heterosexual couples, it should have been proved why there is a difference in treatment for homosexual parents. Importantly, under the Polish law there are no legal unions or partnerships, therefore the legal situation of any couple who has a child together should be identical in the exact same circumstances. The SAC provided some arguments supporting the claim that there is no 'same-sex parents' under Polish law; however, the SAC seems to have failed to prove that such a clear difference in treatment is reasonable and pursues a legitimate aim, and that the treatment is proportional.

One could argue that the legitimate aim is the ordre public or even the preservation of the 'Polish tradition', as brought up by the SAC. Although the member states of the Council of Europe (and European Union) still enjoy a wide margin of appreciation regarding legal recognition of same-sex couples, it has to be noted that the European consensus is slowly emerging. ${ }^{56}$ In addition, as the ECtHR pointed out in Mennesson $v$ France, there cannot be a contradiction between social and legal reality. In this case, avoidance of acknowledging both mothers as parents is to place a tremendous burden upon the child, who will suffer all the consequences of that

54 There is abundant case-law of the ECtHR regarding the topic, e.g. ECtHR, Rasmussen $v$ Denmark, Application no. 8777/79, 21.05.1979; ECtHR, Mikulić v Croatia, Application no. 53176/99, 7.02.2002, etc.

55 ECtHR, Boeckel v Germany, Application no. 8017/11, 7.05.2013.

56 See: Bribosia, E. et al., Same-sex marriage: building an argument before the European Court of Human Rights in light of the US experience, "Berkley Journal of International Law" 2014, Vol. 42, No. 1, pp. 1-43. 
decision. The main goal of the applicant and her child is not only to merely receive an ID or a passport, as the SAC indicated, but to have the identity of the child fully recognised in a dignified manner. One of the most basic pillars of the wellbeing of a child is the relationship with their parents, as is reaffirmed in a multitude of international instruments and in the literature. ${ }^{57}$ Notably, the Polish Constitutional Tribunal as well acknowledged that the best interest of the child does not necessarily require for the relationship to be of biological nature. ${ }^{58}$

According to a survey by the EU Agency for Fundamental Rights, 31\% of the LGBTQ population in Europe are de facto parents as of today. ${ }^{59}$ This is also true for Polish families. Although the refusal to issue a transcript for a child born to a samesex parents may seem insignificant (especially as the SAC indicated measures that might allow the child to receive an ID or a passport), it is proof of a much deeper problem. The SAC missed a chance to ease the plight of Polish children living in LGBTQ families. Even in the third decade of the 21st century, children of same-sex parents still remain on the margins of Polish society and the law.

\section{References}

Alston, P., The best interest principle: towards a reconciliation of culture and human rights, "International Journal of Law, Policy and the Family" 1994, Vol. 8, Issue 1.

Benvenisti, E., Margin of appreciation, consensus and universal standards, "International Law and Politics" 1999, No. 31.

Breen, C., The standard of the best interest of the child, The Hague-London-New York 2002.

Bribosia, E. et al., Same-sex marriage: building an argument before the European Court of Human Rights in light of the US experience, "Berkley Journal of International Law" 2014, Vol. 42, No. 1.

Deterick, S., A commentary on the United Nations Convention on the Rights of the Child, The Hague-Boston-London 1999.

Krawiec, G., Transkrypcja zagranicznego aktu urodzenia dziecka osób tej samej płci pozostających w zwiazku, "Studia Prawnicze. Rozprawy i Materiały" 2019, No. 2(25).

57 See: Breen, C., The standard of the best interest of the child, The Hague-London-New York 2002, p. $20 \mathrm{ff}$.

58 Judgement of the Constitutional Tribunal of 28 April 2003, K 18/02, OTK-A 2003, No. 4, item 32, see furhter: Krawiec, G., op. cit., p. 10.

59 European Union Agency for Fundamental Rights, Report 2019, https://fra.europa.eu/sites/default/ files/fra_uploads/fra-2019-fundamental-rights-report-2019_en.pdf (accessed 25.02.2020). 
Mendecka, K., Klauzula dobra dziecka $w$ Konwencji o prawach dziecka $i$ w prawie polskim (wybrane problemy), “Acta Universitatis Lodziensis. Folia Iuridica” 2016, No. 77.

Mostowik, P., Glosa do wyroku Naczelnego Sądu Administracyjnego z dnia 10 października 2018 r. (sygn. akt II OSK 2552/16), "Zeszyty Naukowe Sądownictwa Administracyjnego" 2019, No. 4.

Mostowik, P., O żadaniach wpisu w polskim rejestrze stanu cywilnego zagranicznej fikcji prawnej pochodzenia dziecka od "rodziców jednopłciowych", "Forum Prawnicze" 2019, No. 6(56).

Parker, S., The best interest of the child - principles and problems, "International Journal of Law, Policy and the Family" 1994, Vol. 8, Issue 1.

Pilich, M., Mater semper certa est? Kilka uwag o skutkach zagranicznego macierzyństwa zastępczego z perspektywy stosowania klauzuli porzadku publicznego, "Problemy Współczesnego Prawa Międzynarodowego, Europejskiego i Porównawczego" 2018, Vol. XVI.

Radwański, Z., Dobro dziecka, in: Łopatka, A. (ed.), Konwencja o prawach dziecka a prawo polskie, Warszawa 1991.

Skoczylas, A. and Swora, M., Administrative judiciary in Poland in search for fairness and efficiency - an overview, "Transylvanian Review of Administrative Sciences" 2007, No. 19E.

Smyczyński, T., Prawo rodzinne i opiekuńcze, Warszawa 2005.

Tadla, T., Glosa do wyroków Naczelnego Sądu Administracyjnego z dnia 10 i 30 października 2018 r. (sygn. akt: II OSK 1869/16, II OSK 2552/16), "Zeszyty Naukowe Sądownictwa Administracyjnego" 2019, No. 3.

Wiącek, M., Omówienie do uchwały NSA z dnia 2 grudnia 2019 r., II OPS 1/19, “Zeszyty Naukowe Sądownictwa Administracyjnego" 2020, No. 1.

Wojewoda, M., Zagraniczne rodzicielstwo osób jednej płci a rejestracja stanu cywilnego w Polsce - glosa do uchwały Naczelnego Sądu Administracyjnego z 2.12.2019 r., II OPS 1/19, "Europejski Przegląd Sądowy" 2020, No. 8.

Zachariasiewicz, M., Klauzula porzadku publicznego jako instrument ochrony materialnoprawnych interesów i wartości fori, Warszawa 2018.

\section{CITATION}

Mendecka, K., Born to Polish same-sex parents - a case study. A human rights perspective on birth certificate transcriptions, "Acta Iuris Stetinensis" 2020, No. 4 (Vol. 32), 33-49,

DOI: 10.18276/ais.2020.32-03. 